\title{
A Meta-Analysis of the Supracondylar Process of the Humerus with Clinical and Surgical Applications to Orthopedics
}

\author{
Metaanálisis del Proceso Supracondíleo del Húmero con \\ Aplicaciones Clínicas y Quirúrgicas para Ortopedia
}

\begin{abstract}
Guilherm Otto Martin-Schütz ${ }^{1}$; Mauricio Arcoverde'; Gustavo dos Reis Barros ${ }^{1}$; Marcio Antonio Babinski ${ }^{1,2}$; Jorge Henrique Martins Manaia ${ }^{2}$; Celso Ricardo Corrêa de Mello Silva ${ }^{1}$; Carlos Alberto Araujo Chagas ${ }^{2}$ \& Lucas Alves Sarmento Pires ${ }^{2}$
\end{abstract}

MARTIN-SCHÜTZ, G. O.; ARCOVERDE, M.; BARROS, R. G.; BABINSKI, M. A.; MANAIA, M. J. H.; SILVA, C. R. C. M.; CHAGAS, C.A.A. \& PIRES, L.A. S. A meta-analysis of the supracondylar process of the humerus with clinical and surgical applications to orthopedics. Int. J. Morphol., 37(1): 43-47, 2019.

SUMMARY: The supracondylar process is a hook shaped projection of the humerus. It is located superior to its medial epicondyle. This anatomic variation is often presented together with the Struther's ligament, a fibrous arcade that connects the supracondylar process to the medial epicondyle. Both structures have been associated with neurovascular bundle compression on the distal third of the arm, as the median and ulnar nerves and the brachial and ulnar arteries may pass through the osteofibrous canal that these variants create. The SciElo, Pubmed, Scopus, TRIP, MEDLINE, COCHRANE and ScienceDirect databases were searched with the term "supracondylar process" or "supracondyloid process" with the purpose of performing a meta-analysis of this bony spur. Heterogeneity between studies was evaluated using I2 estimation and the Cochran Q statistic test. A random effect model was used for all analysis. A total of twenty articles (26.415 humeri) were included in this meta-analysis. The pooled prevalence of the supracondylar process was $0.68 \%$ (95\% Confidence Interval: $0.47 \%$ to $0.92 \%$ ). This variant was more commonly found in women than in men (statistically significant difference) and more commonly found on the left side than the right. The presence of the supracondylar process alone may induce neurovascular bundle compression. It can also be injured in traumatic or stress fractures. Knowledge of this variation and its prevalence may reduce misdiagnosis in radiographic images.

KEY WORDS: Supracondylar process; Anatomical variation; Supracondylar process fracture; Humerus.

\section{INTRODUCTION}

The supracondylar process (SP) of the humerus is a rare anatomic variant situated superior to the medial epicondyle. It can have the shape of a hook or a tubercle and is present in mammals such as cats and lower primates. The SP is also known as the supracondyloid process, supratrochlear spur or the supraepitrochlear process. It was first described by Tiedmann in 1818 (Shivaleela et al., 2014; Caetano et al., 2017).

This anatomic variant possesses a low incidence among different studies, ranging from $0 \%$ to $5.7 \%$, and older researches observed and emphasized the varying incidences in different ethnic groups (Hrdlicka, 1923; Thompson \& Edwards, 2005; Shivaleela et al.).

The SP is sometimes accompanied by a fibrous (sometimes osseous or osteofibrous) arcade known as the
Struther's ligament (Fig. 1), which connects the apex of the SP to the medial epicondyle, thus, forming a tunnel in which the ulnar artery and nerve traverses (the supracondylar foramen) - a disposition also present in cats and in lower primates (De Jesus \& Dellon, 2003; Caetano et al.).

This bony prominence may be appreciated by clinicians and surgeons, as it can cause brachial artery, median nerve, ulnar artery or ulnar nerve compression thus causing neuropathies or vaso occlusive diseases (Thompson \& Edwards; Tzaveas et al., 2010; Bain et al., 2016).

Furthermore, supracondylar fractures are among the most common types of fractures in children, thus, the presence of the SP should be assessed, as it can be fractured as well - despite their rare occurrence (Suresh, 2008; Emery et al., 2015; Pedret et al., 2015).

\footnotetext{
${ }^{1}$ Traumatology and Orthopedic Service, Salgado Filho Hospital, Rio de Janeiro, Brazil.

${ }^{2}$ Morphology Department, Biomedical Institute, Fluminense Federal University, Niterói, Brazil.
} 

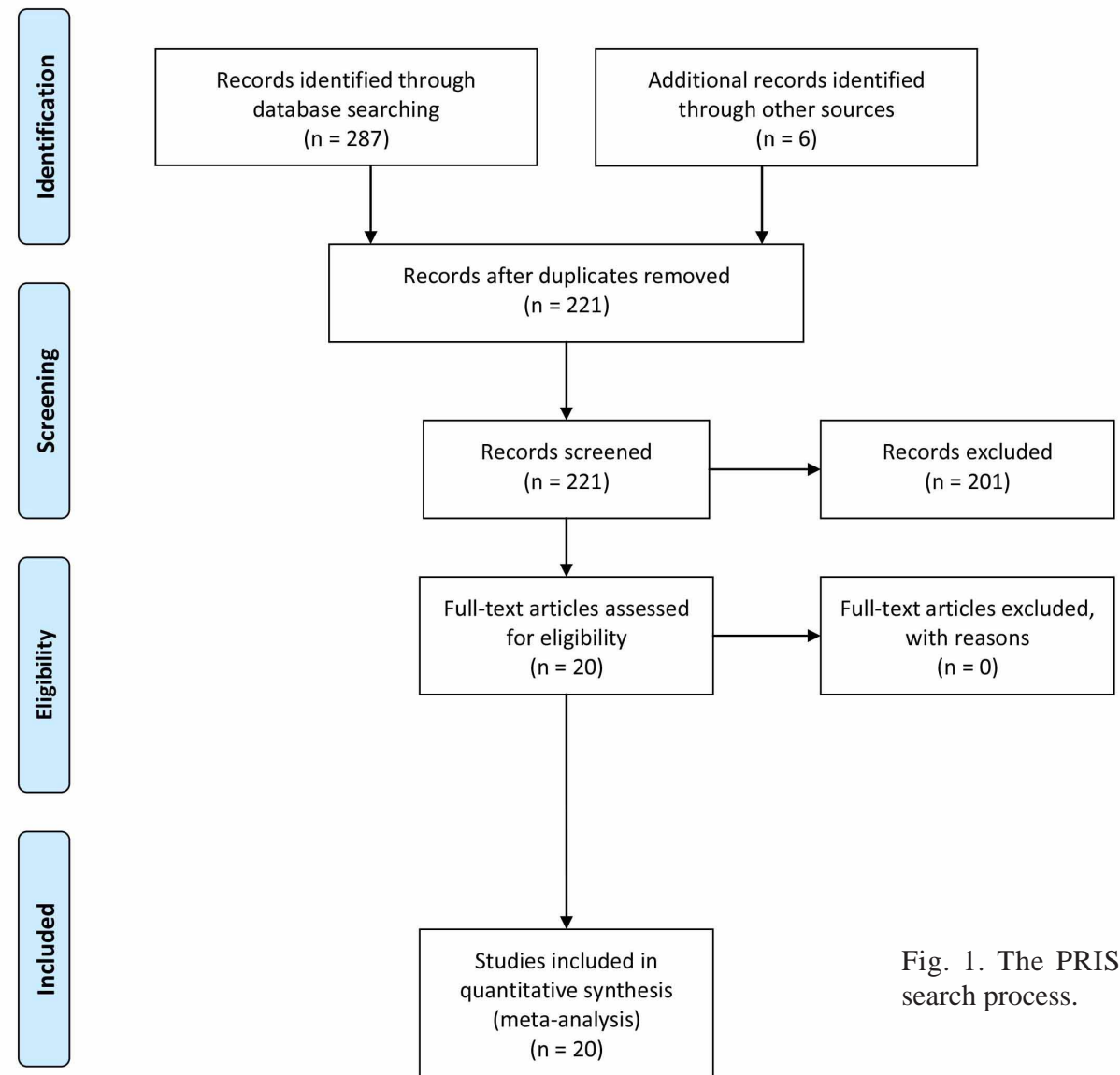

The work presented herein aims to perform a metaanalysis of this bony spur in order to verify the prevalence of this anatomical variant and discuss its anthropological, clinical and surgical significance.

\section{MATERIAL AND METHOD}

\section{Systematic Review and Inclusion and Exclusion Criteria.} This meta-analysis was conducted according to the Preferred Reporting Items for Systematic Reviews and Meta-Analysis (PRISMA) statement (Moher et al., 2009) and the EvidenceBased Anatomy guidelines (Henry et al., 2016). Institutional review board approval was not required. Inclusion criteria for studies in this meta-analysis were: original research manuscripts; scientific journals; papers that involved human patients or involved cadaveric samples with a sample of 20 bones or more. The literature search was performed in April 15, 2018. Editorials, commentaries, letters to the editor, conference abstracts, unavailable articles and case reports were excluded.
Search Strategy. The search was performed in major electronic databases: SciElo, Pubmed, Scopus, TRIP, MEDLINE, COCHRANE and ScienceDirect. There were no restrictions regarding language or date. The terms "supracondylar process" and "supracondyloid process", were separately used for the search process. Furthermore, the reference list of retrieved articles was reviewed in order to identify studies that were not identified from the preliminary literature searches.

Data Extraction and Quality Assessment. Data from the included studies was individually extracted by two reviewers (L.A.S.P., M.A.B.). Data to be extracted included: year, country, total sample size (including side and sex) and prevalence of the SP whenever possible. In the event of any discrepancies, the authors were contacted for clarification, if possible.

Statistical Analysis. Was performed with the MedCalc Statistical Software version 14.8.1 (MedCalc Software bvba, Ostend, Belgium) and the MetaXL version 2.0 by EpiGear Pty Ltd (Wilston, Queensland, Australia). 
Heterogeneity between studies was evaluated using I2 estimation and the Cochran Q statistic test. For all analyses, a random effect model was used. Two-tailed z-test was used in order to compare proportions between the sex and sides of the bones. The chi-square test was performed to verify differences among the regional prevalence of the SP. $\mathrm{P}<0.05$ was considered significant for all statistical analysis.

\section{RESULTS}

Study identification. When the terms "supracondylar process" and "supracondyloid process" were searched separately and yielded in total 517 articles. 3 on SciElo, 69 on Pubmed, 100 on Scopus, 5 on TRIP, 119 on MEDLINE, 1 on Cochrane Library and 220 on ScienceDirect.

After application of exclusion criteria (minus 301 papers), exclusion of repeated articles (minus 124 articles) and reference searching (plus 6 articles), 98 articles were fully reviewed and 20 met the inclusion criteria, and as such, were included. The search process is depicted in Figure 1.

Characteristics of Included Studies. A total of twentyfour studies in twenty articles (Gruber, 1865; Testut, 1889; Terry, 1921; Cady, 1922; Hrdlicka; Pieper, 1925; Cady \& Francis, 1927; Sibata, 1941; Parkinson, 1954; Newman, 1969; Dellon, 1986; Oluyemi et al., 2007; Kumar \& Mehta, 2008; Natsis, 2008; Aydinlioglu et al., 2010; Shivaleela et al.; Hema \& Tanuja, 2015; Caetano et al.) were included in this meta-analysis. The largest number of studies were from the United States of America (8 in total), followed by 5 from India.

Pooled prevalence of the SP. A total of twenty-four studies ( $n=26.415$ humeri) were included in the analysis of the SP. The overall pooled prevalence of the SP was $0.68 \%$ (95\% Confidence Interval [CI]: $0.47 \%$ to $0.92 \%$ ).

Regarding side, the SP was present in $0.71 \%$ (95 $\%$ CI: $0.50 \%$ to $0.96 \%$ ) of 5173 right humeri and in 1.01 $\%$ (95\% CI: $0.68 \%$ to $1.39 \%$ ) of 5167 left humeri in a total of seven studies. This was a statistically significant difference $(\mathrm{p}>0.05)$.

6332 female humeri were analyzed ( 8 studies). The SP was present in $1.24 \%$ (95\% CI: $0.61 \%$ to $2.09 \%$ ) of the female sample. 7818 male humeri were analyzed in the same 8 studies. The SP was present in $0.65 \%(95 \%$
CI: $0.39 \%$ to $0.99 \%$ ) of the male sample. This was considered to be a statistically significant difference ( $\mathrm{p}<$ 0.05). This data can be found in Table I.

Pooled prevalence of the SP by region. Out of 14.000 humeri from studies performed in the American continent ( 8 from the United States of America and 1 from Brazil), $0.57 \%$ (95\% CI: $0.36 \%$ to $0.82 \%$ ) had the SP. In 7806 humeri from studies performed in Asian continent ( 5 from India, one from Turkey, Japan and Korea), the SP was present in $0.52 \%$ (95\% CI: $0.24 \%$ to $0.90 \%$ ) of the sample. 4569 humeri were evaluated in five European studies (three in Germany and one in Italy, France, and Ireland) and $1.13 \%$ (95\% CI: $0.44 \%$ to $2.15 \%$ ) presented the SP. This was statistically significant $(\mathrm{p}<0.05)$. This data can be found in Table II.

Table I. Pooled prevalence of the supracondylar process.

\begin{tabular}{lcc}
\hline Sample (n) & Pooled prevalence (\%) & P value \\
\hline Overall (26415) & $0.68 \%$ & - \\
Left (5167) & $1.01 \%$ & $\mathrm{p}<0.05$ \\
Right (5173) & $0.68 \%$ & \\
Female (6332) & $1.24 \%$ & $\mathrm{p}<0.05$ \\
Male (7818) & $0.65 \%$ & \\
\hline
\end{tabular}

$\mathrm{n}=$ total number of humeri; $\mathrm{P}<0.05$ is considered significant.

Table II. Pooled prevalence of the supracondylar process by continent.

\begin{tabular}{lcc}
\hline Region (n) & Pooled prevalence (\%) & P value \\
\hline America (14000) & $0.57 \%$ & \\
Asia (7806) & $0.52 \%$ & $\mathrm{p}<0.05$ \\
Europe (4569) & $1.13 \%$ & \\
\hline
\end{tabular}

$\mathrm{n}=$ total number of humeri; $\mathrm{P}<0.05$ is considered significant

\section{DISCUSSION}

According to the results presented in this metaanalysis, the prevalence of the SP was $0.68 \%$, a low prevalence among the general population. Our results also showed that it was more prevalent on the left side (statistically significant difference), which is in agreement with other authors (Natsis; Caetano et al.). Despite that, a few authors reported no discrepancies between sides (Hrdlic $k a$; Sibata).

Some studies observed that the SP is more frequent in male bones (Natsis), while others stated or observed that it is more common in women (Hrdlic ${ }^{`} \mathrm{ka}$; Sibata; Caetano et al.). The meta-analysis presented herein showed that this anatomical variant is more prevalent in women (statistically significant difference). 
Its relation with the Struther's ligament was not observed due to the lack of studies that included both anatomical variations in their analysis (most of these studies were performed radiographically or with dry bones). Despite that, it is known that both variations may co-exist. There structures, when present, may serve as an attachment for abnormal muscle bands of the pronator teres and the coracobrachialis muscles (Hema \& Tanuja; Tubbs et al., 2016). Variations such as thee septal aperture (olecranon foramen) (Paraskevas et al., 2012) and high origin of the radial artery (Yazar \& Acar, 2006) have been described in association with the bony spur.

The description of the SP is attributed to Tiedmann in 1822 (Cady; De Jesus \& Dellon; Tubbs et al.), although some authors reported that Tiedmann described it in 1818 and 1819 in apes (Newman; Shivaleela et al.), while the first description of the SP in humans was in 1841 by Knox (Newman).

Both the SP and the Struther's ligament are phylogenetic vestiges of the supracondyloid foramen (which is found in some mammals, especially felines). It can also be found in tarsiers, lemurs, marsupials and some non-human primates (Parkinson; Newman; Caetano et al.).

On another note, the SP has been shown to possess variable prevalence among different populations, however, nowadays, it is hard to compile these data and only a regional approach has been performed in this meta-analysis. Our results showed that bones from Europe are more prone to have the SP than other continents, in accordance with other papers (Parkinson; Caetano et al.) although there is scarce data on African bones for comparison purposes. Parkinson stated that the SP may be inherited, although there are no studies to support this statement.

Clinically, the association of the SP and the Struther's ligament may cause neurovascular bundle compression (Thompson \& Edwards; Tzaveas et al.; Tubbs et al.). Although the presence of the SP alone, is enough to do so (Thompson \& Edwards). Compression of the median nerve (Bain et al.), brachial artery (Thompson \& Edwards; Bain et al.), ulnar artery (Shivaleela et al.) and ulnar nerve (Tzaveas et al.) have been reported in the literature.

The symptoms of vascular compression are usually related to the brachial artery and include ischemic pain, forearm claudication and cyanosis. Nervous compression may cause symptoms such as pain, muscle wasting and numbness. All of these symptoms may be increased by heavy manual work, repetitive activities and during flexion and pronation of the forearm. Furthermore, they may worsen with time (Thompson \& Edwards; Tzaveas et al.; Bain et al.).
Despite that, most of the individuals whom possess the SP and the Struther's ligament are completely asymptomatic (Shivaleela et al.; Hema \& Tanuja; Bain et al.; Caetano et al.). However, some authors proposed that the probability of compression is increased whenever the Struther's ligament is completely ossified (thus turning the supracondylar foramen a bony tunnel) (Tubbs et al.).

The diagnosis of the "supracondylar process syndrome" can be performed clinically with the palpation of the spur and confirmed by radiographies. The "tinel sign" is not reliable, as it can be negative regardless of the compression. Arteriogram should be ordered in case of vascular compression in order to understand the relation of the vessel with the spur (Thompson \& Edwards; Tzaveas et al.; Bain et al.).

The treatment for compression in most cases is the resection (either by open surgery or by endoscopic procedures) (Thompson \& Edwards; Tzaveas et al.; Bain et al.).

Furthermore, the SP may mimic exostosis and bony tumors (osteochondromas) (Mutnuru \& Perubhotla, 2016; Tubbs et al.), thus, knowledge of this anatomic variant and its prevalence may be useful to the differential diagnosis of neurovascular bundle compression.

Fractures due to trauma or stress fractures of the SP, albeit rare, are difficult to treat due to its relation with nervous and vascular structures, especially if there is injury to them (Suresh; Pedret et al.). Since supracondylar fractures are among the most common in pediatric patients, knowledge of this variation should reduce complications during surgery. These fractures are often treated with closed reduction, although open reduction should be preferred when there is neurovascular bundle injury (Brubacher \& Dodds, 2008; Emery et al.; Pedret et al.).

CONCLUSIONS. The SP is a rare variation of the humerus with a predilection to the left side and female populations. It is considered as a phylogenetic remnant of other mammals, especially felines and it can be found together with the Struther's ligament. Further studies are needed to address the prevalence of both anatomical variants.

Its presence may induce neurovascular bundle compression of the median and ulnar nerves, and the brachial and ulnar arteries - although most of the individuals are asymptomatic. Stress or traumatic fractures of the SP are challenging due to its spatial relation to the aforementioned structures.

Knowledge of this rare anatomical variation may prevent misdiagnosis during $\mathrm{X}$-ray evaluations. 
MARTIN-SCHÜTZ, G. O.; ARCOVERDE, M.; BARROS, R. G.; BABINSKI, M. A.; MANAIA, M. J. H.; SILVA, C. R. C. M.; CHAGAS, C. A. A. \& PIRES, L. A. S. Metaanálisis del proceso supracondíleo del húmero con aplicaciones clínicas y quirúrgicas para ortopedia. Int. J. Morphol., 37(1):43-47, 2019.

RESUMEN: El proceso supracondíleo es una proyección en forma de gancho del húmero. Se encuentra superior a su epicóndilo medial. Esta variación anatómica a menudo se presenta junto con el ligamento de Struther, una arcada fibrosa que conecta el proceso supracondíleo con el epicóndilo medial. Ambas estructuras se han asociado con la compresión del paquete neurovascular en el tercio distal del brazo, ya que los nervios mediano y ulnar y las arterias braquial y ulnar pueden pasar a través del canal osteofibroso que crean estas variantes. Se realizaron búsquedas en las bases de datos SciElo, Pubmed, Scopus, TRIP, MEDLINE, COCHRANE y ScienceDirect con el término "proceso supracondíleo" o "proceso supracondiloide" con el objetivo de realizar un metanálisis de este espolón óseo. La heterogeneidad entre los estudios se evaluó mediante la estimación I2 y la prueba estadística Cochran Q. Se utilizó un modelo de efectos aleatorios para todos los análisis. Un total de veinte artículos (26.415 húmeros) se incluyeron en este metanálisis. La prevalencia combinada del proceso supracondíleo fue del 0,68 \% (intervalo de confianza del $95 \%: 0,47 \%$ a 0,92\%). Esta variante se encontró más comúnmente en mujeres que en hombres (diferencia estadísticamente significativa) y se encuentra más comúnmente en el lado izquierdo que en el derecho. La presencia del proceso supracondíleo solo puede inducir la compresión del paquete neurovascular. También puede lesionarse en fracturas traumáticas o por estrés. El conocimiento de esta variación y su prevalencia puede reducir el diagnóstico erróneo en imágenes radiográficas.

PALABRAS CLAVE: Proceso supracondíleo; Variación anatómica; Fractura supracondílea; Húmero.

\section{REFERENCES}

Aydinlioglu, A.; Gumrukcuoglu, F. N. \& Koyun, N. The prevalence of supracondyloid process in the living: a radiographic study. West Indian Med. J., 59(5):545-8, 2010.

Bain, G.; Gupta, P.; Phadnis, J. \& Singhi, P. K. Endoscopic excision of supracondylar humeral spur for decompression of the median nerve and brachial artery. Arthrosc. Tech., 5(1):e67-70, 2016.

Brubacher, J. W. \& Dodds, S. D. Pediatric supracondylar fractures of the distal humerus. Curr. Rev. Musculoskelet. Med., 1(3-4):190-6, 2008.

Cady, L. D. \& Francis, B. F. The supracondyloid process in the feeble-minded. Am. J. Phys. Anthropol., 10(3):387-91, 1927.

Cady, L. D. The incidence of the supracondyloid process in the insane. Am. J. Phys. Anthropol., 5(1):35-50, 1922.

Caetano, E. B.; Neto, J. J. S.; Vieira, L. A.; Caetano, M. F.; de Bona, J. E. \& Simonatto, T. M. Struthers' ligament and supracondylar humeral process: An anatomical study and clinical implications. Acta Ortop. Bras., 25(4):137-42, 2017.

De Jesus, R. \& Dellon, A. L. Historic origin of the "Arcade of Struthers". J. Hand Surg., 28(3):528-31, 2003.

Dellon, A. L. Musculotendinous variations about the medial humeral epicondyle. J. Hand Surg. Br., 11(2):175-81, 1986.

Emery, K. H.; Zingula, S. N.; Anton, C. G.; Salisbury, S. R. \& Tamai, J. Pediatric elbow fractures: a new angle on an old topic. Pediar. Radiol., 46(1):61-6, 2015.

Gruber, W. Ein Nachtrag zur Kenntnis des Processus supracondyloideus (internus) humeri des Menschen. Arch. Anat. Physiol. Wissen Med., 1865:1367-76, 1865.

Hema, L. \& Tanuja, M. Supracondylar process of humerus bone. Int. J. Recent Trends Sci. Technol., 14(1):206-8, 2015.
Henry, B. M.; Tomaszewski, K. A. \& Walocha, J. A. Methods of Evidence-Based Anatomy: a guide to conducting systematic reviews and meta-analysis of anatomical studies. Ann. Anat., 205:16-21, 2016.

Hrdlicka, A. Incidence of the supracondyloid process in Whites and other races. Am. J. Phys. Anthropol., 6(4):405-12, 1923.

Kumar, G. R. \& Mehta, C. D. A Study of the incidence of supracondylar process of the humerus. J. Anat. Soc. India, 57(2):111-5, 2008.

Moher, D.; Liberati, A.; Tetzlaff, J.; Altman, D. G. \& PRISMA Group. Preferred reporting items for systematic reviews and meta-analyses: the PRISMA statement. PLoS Med., 6(7):e1000097, 2009.

Mutnuru, P. C. \& Perubhotla, L. M. Rare mimickers of exostosis: A case series. J. Clin. Diagn. Res., 10(7):TR06-7, 2016.

Natsis, K. Supracondylar process of the humerus: study on 375 Caucasian subjects in Cologne, Germany. Clin. Anat., 21(2):138-41, 2008.

Newman, A. The supracondylar process and its fracture. Am. J. Roentgenol. Radium Ther. Nucl. Med., 105(4):844-9, 1969.

Oluyemi, A. K.; Okwuonu, U. C.; Adesanya, O. A.; Akinola, O. B.; Ofusori, D. A.; Ukwenya, V. O. \& Odion, B. Supracondylar and infratubercular processes observed in the humeri of Nigerians. Afr. J. Biotechnol., 6(21):2439-41, 2007.

Paraskevas, G. K.; Natsis, K.; Anastasopoulos, N.; Ioannidis, O. \& Kitsoulis, P. Humeral septal aperture associated with supracondylar process: a case report and review of the literature. Ital. J. Anat. Embryol., 117(3):135-41, 2012.

Parkinson, C. E. The supracondyloid process. Radiology, 62(4):556-8, 1954.

Pedret, C.; Balius, R.; Alomar, X.; Vilaró, J.; Ruiz-Cotorro, A. \& Minoves, M. Stress fracture of the supracondylar process of the humerus in a professional tennis player. Clin. J. Sport Med., 25(1):e20-2, 2015.

Pieper, I. On the incidence of the supracondyloid process. Am. J. Phys. Anthropol., $8(2): 169-71,1925$

Shivaleela, C.; Suresh, B. S.; Kumar, G. V. \& Lakshmiprabha, S. Morphological study of the supracondylar process of the humerus and its clinical implications. J. Clin. Diagn. Res., 8(1):1-3, 2014.

Sibata, I. The supracondyloid process in Koreans. Okajimas Folia Anat. Jpn., 20(3):347-69, 1941.

Suresh, S. S. Fracture of supracondylar process of the humerus. Sultan Qaboos Univ. Med. J., 8(2):223-5, 2008.

Terry, R. J. A study of the supracondyloid process in the living. Am. J. Phys. Anthropol., 4(2):129-39, 1921.

Testut, L. L'Apophyse sus-epitrochleene chez l'homme. Internat. Monatschr. Anat. Physiol., 1889:6391-433, 1889.

Thompson, J. K. \& Edwards, J. D. Supracondylar process of the humerus causing brachial artery compression and digital embolization in a fast-pitch softball player. A case report. Vasc. Endovascular Surg., 39(5):445-8, 2005.

Tubbs, R. S.; Shoja, M. M. \& Loukas, M. (Eds.). Bergman's Comprehensive Encyclopedia of Human Anatomic Variation. New Jersey, John Wiley \& Sons, 2016.

Tzaveas, A. P.; Dimitriadis, A. G.; Antoniou, K. I.; Pazis, I. G.; Paraskevas, G. K. \& Vrettakos, A. N. Supracondylar process of the humerus: a rare case with compression of the ulnar nerve. J. Plast. Surg. Hand Surg., 44(6):325-6, 2010.

Yazar, F. \& Acar, H. I. Supracondylar process with a high origin of the radial artery. Clin. Anat., 19(8):730-1, 2006

Corresponding author:

Lucas Alves Sarmento Pires

ORCID: 0000-0002-2756-1794

Universidade Federal Fluminense

Instituto Biomédico

Departamento de Morfologia

Rua Prof. Hernani Melo, 101

São Domingos, Niterói

RJ, 24210-130 - BRAZIL

E-mail: lucaspires@id.uff.br

Received: 30-06-2018

Accepted: 17-09-2018 